\title{
INTERAKSI NEUROSAINS HOLISTIK DALAM PERSPEKTIF PENDIDIKAN DAN MASYARAKAT ISLAM
}

\author{
Rusdianto \\ Institute Bisnis Muhammadiyah Bekasi (IBMB) \\ Jl. Jendral Ahmad Yani Blok B2 No. 11 \& 22 Kota Bekasi 17148 \\ E-mail: yantosagarino@yahoo.co.id
}

\begin{abstract}
This article discusses the interaction neorosains holistic education in the perspective of Islam. The concept of Islamic education is the interaction of neuroscience holistic in building the social structure that is controlled through the instrumentation of morality, values, mind control, brain function mind and looked at society as a whole. Holistic neuroscience principles include the principle of commanding the good and forbidding the evil, the principle of integration of science, the principle of solidarity towards the poor, the principle of the spirit of devotion, tajdid principle, the principle of democracy and society. It thus becomes very possible for Muslims to make a picture of an ideal society based pejunjuk Koran.
\end{abstract}

Abstrak. Artikel ini membahas tentang interaksi neorosains holistik dalam perspektif pendidikan Islam. Konsep pendidikan Islam bersifat interaksi neurosains holistik dalam membangun struktur sosial masyarakat yang dikendalikan melalui instrumentasi moralitas, nilai, pengendalian pikiran, fungsi otak akal dan memandang masyarakat secara utuh. Prinsip neurosains yang bersifat holistik meliputi prinsip amar ma'ruf nahi munkar, prinsip integrasi ilmu pengetahuan, prinsip keberpihakan pada kaum dhuafa, prinsip semangat pengabdian, prinsip tajdid, prinsip demokrasi dan kemasyarakatan. Dengan demikian menjadi sangat mungkin bagi umat Islam untuk membuat suatu gambaran masyarakat ideal berdasarkan pejunjuk Alquran.

Kata Kunci: Interaksi Neurosains Holistik, Pendidikan Islam, Masyarakat Islam. 


\section{PENDAHULUAN}

Manusia adalah ciptaan Allah swt. yang tertinggi dan sempurna. Manusia diciptakan sebagai makhluk individu dan sosial. Manusia dalam menjalani kehidupan tidak terlepas dari lingkungan dan tidak dapat hidup menyendiri tanpa bantuan orang lain. Pada hakekatnya pada diri manusia terdapat hasrat yang mendorong untuk hidup bermasyarakat, yakni hasrat mempertahankan diri, berjuang, harga diri, bergaul, kebebasan dan tolong menolong. ${ }^{1}$

Pendidikan Islam berkonsentrasi membangun masyarakat melalui berbagai jaringan kelembagaan. Salah satunya pendidikan Islam yang bercorak modern sesuai dengan perkembangan keummatan. Tujuannya untuk mencerdaskan masyarakat Islam. Sejak awal pendidikan Islam sebagai salah satu media untuk mencapai tujuan kebenaran berdasarkan Alquran dan Sunnah sebagai usaha mengatasi perbuatan menyimpang dalam kehidupan umat dengan tidak mendasarkan dirinya pada madzhab pemikiran tertentu.

Sesuai dengan Undang-undang No. 20 tahun 2003 pendekatan pendidikan Islam dalam pembentukan karakter manusia sangat penting sehingga potensi yang dimiliki peserta didik dalam berbagai kegiatan belajar dapat tercapai dalam kondisi lingkungan yang enak, nyaman dan senang. Selain itu, kurikulum neurosains juga penanaman nilai yang membentuk budi pekerti, nilai seni, nilai budaya, kecerdasan, keterampilan

\footnotetext{
${ }^{1}$ Semua hasrat tersebut manjadikan manusia selalu ingin hidup ditengah-tengah masyarakat dalam usaha untuk memenuhi segala kebutuhannya. Terkait dengan hubungan antara manusia dengan manusia yang lain, agaknya paling penting adalah wujud ideal dari reaksi yang ditimbulkan sebagai akibat dari hubunganhubungan tadi. Adanya reaksi tersebutlah yang menyebabkan tindakan sesorang menjadi lebih luas dan lebih baik didalam memberikan reaksi tersebut, ada kecenderungan manusia untuk memberikan keserasian dengan tindakantindakan orang lain. Lihat Abu Ahmadi, Sosiologi (Surabaya; PT. Bina Ilmu, 1985), h. 37
} 
dan agama. ${ }^{2}$ Dengan pemikiran seperti itu, neurosains bersumber pada wahyu sebagai kawasan transendental yang rasional, empiris dan intuitif.

Pendidikan menempati posisi strategis dalam rangka mencerdaskan masyarakat. Visi pendidikan Islam harus mengutamakan pengembangan intelektual peserta didik pada setiap jenis dan jenjang pendidikan dan jenjang strata sosial dengan menegakkan dan menjunjung tinggi nilai keislaman dan kemanusiaan melalui dakwah Islam di seluruh aspek kehidupan. Setiap tujuan pendidikan Islam selalu berhubungan dengan pandangan hidup negara.

Pendidikan Islam menyatukan IQ, EQ SQ. Penyatuan tersebut membentuk keseimbangan antara pengembangan kognitif, afektif dan psikomotorik. Namun, hal ini belum menjadi komitmen kolektif pemerintah dan lembaga pendidikan Islam untuk mewadahi kecerdasan akal, jasmani, kognitif, afektif dan psikomotorik. $^{3}$

Saat ini, penting untuk memasukkan mata pelajaran tentang akal (neurosain) dalam kurikulum pendidikan Islam. Dalam konteks pendidikan Islam, kecerdasan merupakan hal pokok dalam pengembangan potensi peserta didik terlebih pada pembentukan karakter dan rasionalitas, seperti IQ, EQ, SQ, MaQ, dan Multiple Intellegence. ${ }^{4}$

Sebagai ajaran (doktrin) Islam mengandung sistem nilai dimana proses pendidikan Islam berlangsung dan dikembangkan

${ }^{2}$ Pendekatan pendidikan dalam pembentukan karakter sangat penting sekali untuk di didik secara tepat supaya menjadi manusia yang berkualitas. Lihat falsafah Undang-undang No. 20 tahun 2003

${ }^{3}$ Suyadi, "Integrasi Pendidikan Islam dan Neurosains dan Implikasinya Bagi Pendidikan Dasar (PGMI)” dalam Jurnal Al-Bidāyah, Vol 4 No. 1, (Juni 2011), h. 17

${ }^{4}$ Agus Nggermanto, Quantum Qoutient (Kecerdasan Quantum): Cara Praktis Melejitkan IQ, EQ, dan SQ Yang Harmonis, (Bandung: Nuansa, 2005), h. 44 
secara konsisten menuju tujuannya. Sejalan dengan pemikiran ilmiah dan filosofis dari pemikir-pemikir muslim, sistem nilai itu kemudian dijadikan dasar bangunan (struktur) pendidikan Islam yang memiliki daya lentur normatif menurut kebutuhan dan kemajuan. Pendidikan Islam mengidentifikasi sasarannya yang digali dari sumber ajarannya yaitu Alquran dan Hadis, meliputi empat pengembangan fungsi manusia, yakni: ${ }^{5}$ pertama: menyadarkan secara individual pada posisi dan fungsinya ditengah-tengah makhluk lain serta tanggung jawab dalam kehidupannya; Kedua: Menyadarkan fungsi manusia dalam hubungannya dengan masyarakat, serta tanggung jawabnya terhadap ketertiban masyarakatnya. Ketiga: Menyadarkan manusia terhadap pencipta alam dan mendorongnya untuk beribadah kepada Nya. Menyadarkan manusia tentang kedudukannya terhadap makhluk lain dan membawanya agar memahami hikmah di balik penciptaan, serta memberikan kemungkinan kepada manusia untuk mengambil manfaatnya.

\section{PEMBENTUK INTERAKSI NEUROSAINS}

Neurosains, secara sederhana adalah ilmu yang khusus mempelajari Neoron (sel saraf). Sel-sel saraf ini menyusun sistem saraf, baik susunan saraf pusat (otak dan saraf tulang belakang) maupun saraf tepi (31 pasang saraf spinal dan 12 pasang saraf kepala). Sel saraf (Neuron) adalah sinapsis yaitu titik pertemuan 2 sel saraf yang memindahkan dan meneruskan informasi neurotransmitter.

Pada tingkat biologi molekuler, unit terkecilnya adalah seperti gen-gen (kajian genetika). Umumnya para neurosaintis memfokuskan pada sel saraf yang ada di otak. Sebagai ilmu yang masih terus akan berkembang cakupan dan relasinya dengan

${ }^{5}$ Ibn Taimiyah (1263-1328) dan Ibn al-Qayyim al-Jazu (1292-1350 M.), Ahmad Dahlan (1912), dalam Russell Ackoff I dan Daniel Greenberg, Turning Learning Right Side Up. Putting Education Back on The Right Track. Upper Sadle River, (NJ: Pearson Ed. Inc. Canton, 2008). h. 311 
disiplin ilmu lain, termasuk dengan ilmu psikologi cakupannya cukup luas sebagaimana digambarkan dalam kamus wikipidia (internet searching) berikut ini:

"Neuroscience is a field that is devoted to the scientific study of the nervous system. Suchstudies span the structure function, evolutionary history, development genetics, biochemistry, physiology, pharmacology, informatics, computational neuroscience and Pathology of the nervous system. Traditionally it is seen as a branch of biological sciences. However, recently there has been a surge in the convergence of interest from many allied disciplines, including cognitive and neuropsychology, computer science, statistics, physics, and medicine. The scope of neuroscience has now broadened to include any systematic scientific experimental and theoretical investigation of thecentral and peripheral nervous system of biological organisms. The empirical methodologies employed by neuroscientists have been enormously expanded, from biochemical and genetic analysis of dynamics of individual nervecells and their molecular constituents to imaging representations of perceptual and motor tasks in the brain. Many recent theoretical advances in neuroscience have been aided by the use of computational modeling". ${ }^{6}$

Neurosain juga terdapat dalam Alquran yang menjelaskan aktifitas otak, seperti tafakkur (berpikir), tadabbur (merenung), tabașșur dan (memahami). Pemaknaan kalimat tersebut dikonstruksikan secara kreatif (meaning of creatifity), sebagaimana ayat Alquran menggunakan istilah neurosain. ${ }^{7}$ Oleh karena itu, neurosain dalam pendidikan Islam memungkinkan untuk diintegrasikan. ${ }^{8}$

Sesuai ungkapan "dan (juga) pada dirimu sendiri, maka apakah kamu tidak memperhatikan", , pada suatu hari seorang

${ }^{6} \mathrm{http} / / /$ www.wikipedia.com (di Akses pada tanggal 22 April 2015)

${ }^{7}$ Diantaranya Q.S. Al-Baqarah [2]: 219; Q.S. Al-Imran [3]: 191; Q.S. AlAn'am [6]: 50; Q.S. Al-A'raf [7]: 176 \& 184; Q.S. Yunus [10]: 24; Q.S. Al-Ra'd [13]: 3; Q.S. An-Nahl [16]: 11,44 \& 69; Q.S. Ar-Rum [30]: 8 \& 21; Q.S. Saba' [34]: 46; Q.S. Al-Zumar [39]: 42; Q.S. Al-Jāšiyah [45]: 13; Q.S. Al-Hasyr [59]: 21 dan Q.S. AlMuddašsir [74]: 18

${ }^{8}$ Noeng Muhadjir, Metodologi Penelitian, Edisi VI, (Yogyakarta: Rake Sarasin, 2011), h. 318

${ }^{9}$ Q.S. Al Żāriyāt [51]: 21 
Syahdan menamakan sebuah kota di Phacis, Yunani Tengah, pada zaman purba, di lereng gunung Parnassos, dikenal dengan nama Delphi, pusat ibadat Apollo, tempat orakel Delphi yang terkenal. Pada orakel dipahatkan sebuah kalimat, yang konon berasal dari ucapan Sokrates (470-399 SM), berbunyi "gnothi seauthon" (kenalilah dirimu). ${ }^{10}$ Sokrates-lah yang pertama mengundang perhatian manusia untuk memperhatikan dirinya sendiri. Dengan perkataan lain, Sokrates mengundang perhatian segala yang dimasalahkan oleh manusia itu dengan dimulai dari manusia sendiri sebagai masalah. ${ }^{11}$ Sesuai ungkapan dalam Hadis "man 'arafa nafsah faqad 'arafa rabbah" (barang siapa yang mengenal dirinya sendiri (kenalilah dirimu), berarti dia mengenal Tuhannya. ${ }^{12}$

Oleh sebab itu, sebelum sampai kepada pengertian konsep al-'aql secara utuh, dalam kehidupan sehari-hari terdapat suatu fenomena tentang otak dan akal. Ibarat dua sisi dari mata uang logam, sulit dipisahkan baik kata maupun makna karena keduanya ada keterikatan kuat sehingga perlu dijelaskan. Otak adalah organ tubuh manusia yang posisinya ditempatkan Tuhan secara terhormat dibagian atas tubuh manusia dan terlindungi dengan kokoh di bagian dalam tengkorak kepala. Posisi otak ini merupakan simbol yang menunjukkan bahwa manusia lebih mulia dari pada makhluk ciptaan Tuhan lainnya, misalnya hewan yang lokasi dan posisi otaknya sejajar dengan bagian tubuh dan tempat meyimpan dan mengeluarkan kotorannya (perut dan dubur atau tumbuhan yang tidak mempunyai otak dan tidak diketahui dimana posisi otaknya jika ada.

\footnotetext{
${ }^{10}$ Hasanuddin Arinta Kusrin, Akal: Menurut Tinjauan Al qur'an dan Neurosains, (Jakarta: Universitas Indonesia, 2009), h. 4

${ }^{11}$ Endang Saifuddin Anshari, Ilmu, Filsafat dan Agama, (Jakarta: PT. Bina Ilmu, 1983), h. 34

${ }^{12}$ Sebenarnya bukan hadis, Seyyed Hossein Nasr mengutipnya dengan mengatakan bahwa penjelasan hadis ini dinisbahkan kepada Ibn Arabi, tetapi sesungguhnya ditulis oleh Auhad Al-Din Balyani, Whose Knoweth Himself, terj. T.H.Weir (London: Beshara, 1976).
} 
Muhammad Izuddin Taufiq mengatakan bagian tubuh yang paling ambigu yang masih menyelimuti tubuh manusia adalah otak karena ia merupakan tempat berfikir yang berkaitan dengan roh atau jiwa, sedangkan roh atau jiwa itu merupakan sesuatu yang ambigu. ${ }^{13}$

Maka tidak heran, jika ada yang menyamakan makna antara otak dan akal, begitu juga yang membedakannya. Harun Nasution termasuk orang yang membedakan, dan menyatakan bahwa akal dalam pengertian Islam bukanlah otak, melainkan daya berfikir yang terdapat dalam jiwa manusia; daya sebagaimana digambarkan Alquran, memperoleh pengetahuan dengan memperhatikan alam sekitarnya. ${ }^{14}$

Otak adalah organ tubuh yang bukan hanya manusia, binatang pun memilikinya. Ketika otak bekerja, salah satunya adalah berpikir, maka otak yang bekerja atau berfungsi tersebut disebut akal. Orang yang tidak berotak adalah orang yang tidak menggunakan otaknya berfungsi atau berpikir. Otak yang berfungsi dan disebut akal inilah yang membedakan manusia dengan binatang melata. Manusia itu adalah hewan yang berpikir (al-insān hayawān nạtiq, man as the animal that reasons).

Ibnu Sina (980-1037), filosof muslim yang terkenal di timur dan barat menyatakan bahwa manusia mempunyai kemampuan, yaitu makan, tumbuh, berkembang biak, pengamatan hal-hal yang istimewa, pergerakan di bawah kekuasaan, ketahuan (mengetahui) dari hal-hal yang umum, dan memiliki kehendak memilih yang bebas. Tumbuh-tumbuhan hanya memiliki kemampuan 1, 2 dan 3, sedangkan hewan memiliki kemampuan 1, 2, 3, 4, dan 5. Kemampuan 6 dan 7 yang ada pada manusia sangat potensial membudi dayakan otak untuk berfikir yang tidak

\footnotetext{
${ }^{13}$ Muhammad Izzududdin Taufik, Dalil Anfus Al Quran dan Embriologi, (Solo Tiga Serangkai, 2006), h. 209

${ }^{14}$ Taufik Pasiak, Revolusi IQ/EQ/SQ Antara Neurosains dan Al Quran, (Bandung: Penerbit PT.Mizan Pustaka, 2004), h. 190.
} 
dimiliki oleh makhluk ciptaan Allah lainnya dan membedakannya, ${ }^{15}$ bahkan juga membedakan antar sesama manusia ketika manusia tidak mau mempergunakan otaknya untuk berfikir.

Ibnu Khaldun (1332-1406), menjelaskan bahwa Allah membedakan manusia dengan hewan dengan kesanggupan berpikir, sumber dari kesempurnaan dan puncak dari segala kemuliaan dan ketinggian di atas makhluk lain. Kesadaran dalam diri tentang peristiwa di luar dirinya, hanyalah hewan saja, tidak terdapat pada mahluk lain. ${ }^{16}$ Sebab hewan menyadari akan apa yang ada di luar darinya dengan perantaraan panca indra (pendengaran, penglihatan, pembauan, perasaan lidah dan penyentuhan) yang diberikan Allah pada hewan. Namun, berbeda dengan hewan, manusia memahami dirinya dengan pikiran dan panca indranya. Pikiran bekerja dengan perantara kekuatan otak yang memberi kesanggupan untuk menerima dan merasakan oleh panca indra, dan mengembalikan dalam ingatannya sambil meringkas dan menjelaskan apa yang dirasakannya. Refleksi terdiri dari penjamahan bayangan-bayangan ini (dibalik perasaan) oleh akal, yang memecah atau menghimpun bayanganbayangan itu (untuk membentuk bayangan-bayangan lain). ${ }^{17}$

Menurut Imam al-Ghazali (1058-1111), ${ }^{18}$ dengan mengacu pada pengertian kerja dan fungsi akal menyatakan bahwa akal itu tidak bertempat, baik di dalam maupun di luar badan manusia, bersifat immaterial, dan tidak terbagi-bagi. Akal berhubungan dengan badan dalam bentuk $^{19}$ (1) muqbil 'alā al-badan (menghadap badan), (2) mufíd lah (memberi keuntungan), dan (3)

\footnotetext{
1986), h. 13.

${ }^{15}$ Harun Nasution, Akal dan Wahyu Dalam Islam, (Jakarta: UI Press,

${ }^{16}$ Dikutip dalam Taufik Pasiak, Revolusi..., h. 205.

${ }^{17}$ Ibid., Endang Saifuddin Anshari, Ilmu, Filsafat..., h. 6.

${ }^{18}$ Muhammad Yasir Nasution, Manusia Menurut Al-Ghazali, (Jakarta: Penerbit Rajawal Press), 1988.

${ }^{19}$ Dikutip dalam Taufik Pasiak, Revolusi ..., h.190
} 
mufîd 'alaih (mengalir kepadanya). Tiga bentuk ini menitikberatkan pada fungsi, proses atau kegiatan. Akal sebagai organ yang mengikat dan menahan secara filosofis juga dijelaskan oleh pemikir Islam Syed Muhammd Naquib Al Attas, adalah sesuatu organ aktif dan sadar yang mengikat dan menahan objek ilmu dengan kata-kata atau bentuk-bentuk perlambang lain. Ini menunjukkan pada fakta yang sama dan bermakna sama dari apa yang ditunjuk oleh kata qalb, rūh, dan nafs. Sebagaimana Al Ghazali, Al-Attas berpendapat bahwa keempat kata itu bermakna sama. Kesemuanya menunjukkan realitas yang bertingkat-tingkat (marātib al-wujūd). ${ }^{20}$

Pada masa Islam, akal hanya berarti kecerdasan praktis yang ditunjukan seseorang dalam situasi yang berubah-ubah. Akal berhubungan dengan pemecahan masalah karena bersifat praktis kognitif sebagai problem solving capacity (kemampuan untuk memecahkan masalah dan menemukan jalan keluar dalam situasi apapun. ${ }^{21}$ Seorang penyair Islam Al-Shanfara, sebagaimana dikutip oleh Toshihiko Izutsu, ${ }^{22}$ telah memakai kata itu dengan makna praktisnya dalam syairnya:

“selama seseorang menggunakan kecerdasannya (wa huwa ya'qilu) maka tidak akan tarjadi peristiwa yang memalukan ketika ia tidak tahu apa yang harus dilakukan, entah ketika ia berada di jalan yang akan ia tuju, atau tergesa melepaskan diri dari sesuatu yang dibencinya".

Dengan syair diatas, tampak bahwa kata aql dalam Alquran sudah menjadi dasar dalam membangun komunikasi dan interaksi bersama masyarakat, sebagaimana banyak di jelaskan dalam Alquran. Izutsu mengkaitkan akal dengan kecerdasan, maka akal adalah kecerdasan praktis (mengikat) dan menahan sebagai makna dasar kata Aql lebih cocok dengan kegiatan penalaran logis, sebuah cara berpikir yang mengandalkan fakta dan

${ }^{20}$ Ibid., h. 197.

${ }^{21}$ Ibid, h. 194

${ }^{22}$ Toshihiko Izutsu, Relasi Tuhan dan Manusia Pendekatan Semantik Terhadap Al Quran, (Yogyakarta: Penerbit Tiara Wacana, 1997). h. 171. 
langkah-langkah rasional. Untuk makna ini, kata aql lebih mungkin disebut reason (Inggris), rasio (Latin), verstand (Jerman), dan dianoia (Yunani).

Kata 'aql ini cocok untuk menyebut cara kerja dari otak kiri yang berpikir secara vertical. Baik Harun, Gazali, maupun Al-Attas membedakan dan memisahkan otak dan akal, bahkan cenderung menyiratkan pengertian akal itu kerja jiwa (qalb, rūh dan nafs). Sebagaimana juga dinyatakan oleh Ibnu Khaldūn bahwa akal itu kerja otak baik kognitif maupun imajinatif dengan jelas tersirat dan tersurat pada Q.S. al-Anfāl (8): 22 dan Q.S. al-A'rāf (9):179. Dengan demikian bahwa akal berfungsi mengoperasionalkan otak yang bekerja berpikir. Allah swt., dalam Q.S. al-Anfāl (8): 22 tidak menggunakan kalimat yang tidak menggunakan otaknya, adalah hikmah tersembunyi untuk memotivasi manusia agar memperhatikan dirinya, menggunakan otaknya, untuk meneliti (men-tafakkuri dan men-tadabburi) tentang organ otak.

Juga untuk memahami dan cara kerja otak yang berkaitan dengan akal, jiwa (qalb), ruh dan nafs serta model mentafakkuri dan mentadabburiayat-ayat Allah baik yang tertulis dalam Alquran maupun alat transmisi pesan berupa panca indra yang melakukan interaksi sosial diantara sesama yang menjadi objek penelitian, pengamatan dan penjelajahan.

Kadangkala kita mengatakan akal pikiran, karena otak yang berpikir pertanda otaknya berfungsi dan menunjukkan eksistensi akal atau pikiran, sebagaimana pernah dikatakan Plato bahwa bepikir itu berpusat di kepala, begitu juga dengan Rene Descartes bahwa pusat jiwa ada di kelenjar pineal otak maka kalimat yang muncul cogito ergo sum (aku berpikir, sebab itu aku ada). Sedangkan Michael Persinger dan Vilyanur Ramachan dran, ahli bedah otak dari Amerika pada dekade akhir abad 20 menyebutkan dalam penelitiannya tentang otak menyimpulkan ada fenomena god spotdalam lobus temporalis otak (sekitar pelipis). 
Pada dekade otak (1990-2000) ${ }^{23}$ dimana penemuan moleculer biology of cognition (MBC), telah mampu mencitrakan kemampuan otak organ ciptaan Tuhan melampaui apa yang diketahui selama ini, termasuk apa yang sebelumnya diketahui oleh Ibn Sina dan Ibn Rusyd, yang menjelaskan daya-daya berfikir manusia dan Ibnu Khaldun yang menjelaskan peran otak dalam proses berpikir serta Rene Descartes yang berkata tentang Cogito (pikiran) manusia. Penemuan MBC tersebut memperlihatkan bahwa hal-hal kejiwaan manusia seperti berpikir, merasa, emosi, ingatan, persepsi, yang dahulu menjadi lahan mutlak para filosof dan psikolog dan karena itu sangat spekulatif kini dapat ditelaah secara lebih lugas dan jelas. Begitu juga penemuan tentang neurotransmiter, amig dalam, dan sistem limbik pada otak memberikan pengetahuan mengenai apa yang disebut akal itu.

Tentang hubungan otak dan jiwa, beberapa puluh tahun lalu, ahli otak John Eccles dalam bukunya, The Understanding of the Brain mengatakan, bahwa secara teoritis ia menggunakan konsep 3 (tiga) dunia dari Karl Popper untuk menjelaskan hubungan otak dan jiwa manusia. Neurosaintis Erick Kandel, yang memperoleh nobel kedokteran, membuktikan hubungan otak dan jiwa melalui risetnya soal memori siput apylasia californica. Ia berhasil membuktikan secara molekuler, kejadian pada sel-sel saraf untuk menguatkan teori psikologi mazhab Behaviourisme, terutama penemuan Ian Pavlov. Pavlov terkenal dengan classical conditioning yang menyatakan bahwa respons makhluk hidup (ketika meneliti, ia menggunakan hewan percobaan berupa anjing) dapat dikondisikan melalui pengkondisian stimulus. Penemuan Pavlov yang semula masuk kewilayah psikologi kini masuk wilayah molekuler. Perilaku anjing (kondisi psikologi) terjadi karena adanya pelepasan molekul saraf di ujung sel-sel saraf (kondisi neurobiologi). ${ }^{24}$

${ }^{23}$ Taufik Pasiak, Manajemen Kecerdasan, (Bandung : Mizan, 2006), h. 21.

${ }^{24}$ Taufik Pasiak, Revolusi ..., h.190 
Otak kita secara jasmani (fisik) memiliki kemampuan berjuta kali lebih hebat dari computer manapun yang ada dan terhebat di dunia. Otak kita bekerja mirip seperti CPU (Central Processing Unit) dalam sistem komputer. Jika seekor lalat buah memiliki 100.000 sel aktif, seekor tikus memiliki 5 juta sel aktif, seekor kera 10 miliar sel aktif, maka manusia memiliki sekitar 100 miliar sel aktif sejak lahir. Dan sejak hari pertama kehidupan selsel tersebut membentuk koneksi belajar (sinapsis) dengan kecepatan luar biasa sampai 3 miliar perdetik. ${ }^{25}$

Tony Buzan, seorang pakar psikologi dan memori, mengatakan, otak terdiri dari triliunan sel otak. Setiap sel otak adalah seperti gurita kecil yang begitu kompleks. Ia memiliki sebuah pusat, dengan banyak cabang, dan setiap cabang memiliki banyak koneksi. Tiap-tiap sel otak tersebut jauh lebih kuat dan canggih dari kebanyakan computer di planet ini. Setiap sel tersebut berhubungan dengan ratusan ribu sampai puluhan ribu sel yang lain. Dan mereka saling bertukar Informasi. Ini sering disebut sebagai jaringan paling mempesona, benda yang begitu kompleks dan indah. Dan setiap orang memilikinya.

Roger Sperry, pemenang Nobel Prize, tahun 1981 dalam penelitian tentang otak menemukan perbedaan kemampuan fungsi otak berdasarkan 2 (dua) belahan yaitu otak kiri dan kanan. Secara umum, otak kiri memainkan peranan dalam proses logika, kata-kata, matematika, dan urutan yang disebut pembelajaran logis akademis, sedangkan otak kanan berurusan dengan irama, rima, musik, gambar dan imajinasi yang disebut dengan aktivitas intuitif keatif. Kedua sisi belahan otak terebut terhubung melalui corpus callosum sistem saklar saraf yang sangat rumit dengan 300 juta neuron aktifnya bekerja secara konstant menyeimbangkan

\footnotetext{
${ }^{25}$ Sel Otak (Neuron) bekerja membentuk jaringan koneksi (sinapsis), dimana neurotransmittersangat berperan membawa informasi antar jaringan, membuat otak kita berfungsi optimal (berfikir) dan menunjukkan bagaimana akal berfungsi. Gordon Dryden \& Jeannette Vos, Revolusi Cara Belajar, (Bandung: Kaifa. 2000), h. 113.
} 
pesan-pesan atau informasi yang datang, dan menggabungkan gambar yang abstrak dan holistik dengan pesan (informasi) yang konkret dan logis. Kemampuan belahan otak kiri dan kanan dan tampak terlihat aktivitas otak saat membaca buku pada bagian berwarna putih di lobus temporal, lobus parietal dan beberapa pada lobus oksipetal yang menggunakan pencitraan dari alat PET (Pesitron Emission Tomografhy).

Otak manusia memiliki empat bagian tingkatan otak dalam satu kesatuan yang berbeda, yaitu di bagian bawah, yakni batang otak, dekat bagian atas leher, disebut otak reptilia, karena mirip dengan otak reptil berdarah dingin. Bagian ini mengendalikan sebagian besar fungsi naluriah tubuh, seperti bernafas dan detak jantung. Di bagian tengah, yakni otak mamalia, (sistim limbik cincin kerah) mirip otak mamalia berdarah panas. Bagian ini mengendalikan emosi, keinginan (kesenangan) terhadap lawan jenis dan memori (ingatan). Di bagian atas, yakni korteks (otak manusia), yakni otakuntuk berfikir, berbicara, melihat, mendengar dan mencipta. Lapisan cerebellum (serebelum): Otak kecil yang berperan penting dalam penyimpanan memori gerak (naik sepeda, berolah raga). ${ }^{26}$

Pada tahun 1990 Paul Mc. Lean mengembangkan teori The Triune Brain yang membagi otak menjadi tiga lapis. Teori ini merupakan pengembangan dari teori yang dikembangkan oleh Selye tahun 1952 yang dikenal dengan general adaption syndrome (GAS) atau disebut Fight Or Flight Response. Teori The Triune Brain membagi proses evolusi perkembangan otak dalam tiga tahapan atau tiga lapisan. ${ }^{27}$

Lapis pertama, yang terletak dibagian luar dan muncul paling terakhir dalam evolusi biologis ini adalah otak berpikir. Lapis ini secara molekuler juga bersifat unik, yaitu menata fungsi-

\footnotetext{
${ }^{26}$ Ibid.

${ }^{27}$ Taufik Bahaudin, dalam Hasanuddin, Brainware Management, (Jakarta: PT. Elex Media Komputindo, 2001). h. 41.
} 
fungsi kognisi manusia, seperti bahasa dan memori kognitif. Jika lapisan ini rusak, kita akan kehilangan kemampuan berpikir tingkat tinggi, terutama yang menggunakan bahasa dan kalkulasi matematis. Lapisan ini membentuk rasionalitas berfikir. Dibandingkan dengan sistem limbik (lapisan kedua), lapisan otak berpikir ini relatif mampu untuk memilih dan respons. Tidak ada respons fight atau flight. Perbedaan paling bermakna antara lapisan otak berpikir dan otak binatang adalah kemampuan memilih respons. Ciri khas otak manusia yang dibangun terutama oleh otak berpikir ini adalah kebebasan untuk memilih respons atas setiap stimulus yang masuk.

Jika ada seseorang mencela (menghina), maka otak berpikir yang berfungsi memandu dan merespon dengan tindakan dalam bentuk marah, bisa tertawa karena menganggap hinaan itu lucu, bisa juga berdiam diri karena menganggap bahwa membuang waktu dan tenaga jika harus merespon hal-hal kecil seperti ini. Pilihan atas tiga respons itu menunjukan bahwa kita betul-betul menggunakan otak berpikir. Jadi, jika sekiranya depresi dan stres berat karena hinaan orang, itu berarti diri sendiri yang menciptakaan perasaan tidak nyaman. Kebebasan memilih respons ini menandai kemanusiaan dan kedewasaan. Tidak semua manusia menjadi dewasa sejalan dengan bertambahnya usia.

Jika ia membesarkan dan menyuburkan otak binatang dalam kepalanya, maka ia akan hidup dengan cara binatang. Bentuk tubuhnya seperti manusia, tetapi cara berpikirnya seperti binatang. Hilangnya fungsi otak berpikir, dan diambil oleh otak binatang, dicirikan oleh nafsu tak tekendali yang bersifat kepemilikan dan seksualitas. Jika kita terlalu bernafsu untuk memiliki barang, menumpuk tanpa manfaat yang bermakna, itu juga artinya otak binatang kita sedang bekerja. Persis seperti perilaku nenek moyang yang menyimpan dan menimbun barang dan binatang hasil buruan. 
Demikian juga ketika kita mengumbar hawa nafsu seks secara tak terkendali tanpa memperhatikan aturan main dan norma, itu berarti otak binatang sedang bekerja. Persis seperti nenek moyang dulu yang bebas melakukan hubungan seks dengan pasangan berganti-ganti. Lapisan ketiga adalah otak vegetasi, bagian otak yang bertanggungjawab terhadap fungsi pola mempertahankan hidup, napas, pengaturan tekanan darah, penataan kulit, otak dan tulang, serta keterjagaan (awakening).

Salah satu bagian penting lapis ketiga ini adalah RAS (reticular activating system) yang bertangungjawab menjaga manusia untuk setiap respons dari luar. Jika bagian ini rusak, maka menjadi tidak terjaga terhadap hal-hal yang penting dalam kehidupan biologis manusia. Kemampuan menata RAS (Reticular Activating System) memungkinkan mengontrol fungsi vegetasi. Ketiga bagian otak bekerja sebagai satu kesatuan.

\section{PENDIDIKAN ISLAM NEUROSAINS HOLISTIK DAN MASYARAKAT ISLAM}

Dasar pelaksanaan pendidikan Islam terutama adalah Alquran dan hadis. Alquran diturunkan kepada umat manusia untuk memberi petunjuk kearah jalan hidup yang lurus dalam arti memberi bimbingan dan petunjuk kearah jalan yang di ridhai Allah SWT. Menurut Hadis Nabi, bahwa "diantara sifat orang mukmin ialah saling menasihati untuk mengamalkan ajaran Allah", yang dapat diformulasikan sebagai usaha atau dalam bentuk pendidikan Islam. Ketiga, Alquran dan hadist tersebut menerangkan bahwa nabi adalah benar-benar pemberi petunjuk kepada jalan yang lurus, sehingga beliau memerintahkan kepada umatnya agar saling memberi petunjuk, memberikan bimbingan, penyuluhan, dan pendidikan Islam. Bagi umat Islam maka dasar agama Islam merupakan fondasi utama keharusan berlangsungnya pendidikan. Karena ajaran Islam bersifat 
universal yang kandungannya sudah tercakup seluruh aspek kehidupan ini. ${ }^{28}$

Mohammad Athiyah Abrosyi dalam kajiannya tentang pendidikan Islam telah menyimpulkan 5 tujuan yang asasi bagi pendidikan Islam dalam pembentukan karakter masyarakat yaitu: ${ }^{29}$ pertama, untuk membantu pembentukan akhlak yang mulia, maka pendidikan Islam merupakan benteng bagi masyarakat. Kedua, pendidikan Islam juga sebagai persiapan kehidupan dunia akhirat serta memperbaiki hubungan yang di bangun masyarakat. Ketiga, menumbuhkan ruh ilmiah pada pelajaran, mengetahui dan mengkaji ilmu agar menumbuhkan minat sains, sastra, kesenian, dalam berbagai jenisnya. Keempat, menyiapkan output pelajar profesional, teknis, supaya dapat menguasai profesi teknis tertentu dan memelihara kemasyarakatan. Kelima, pendidikan Islam sebagai bentuk pola pemeliharaan agama, akhlak, spritual dan tujuan membangun relasi masyarakat sesuai aktivitasnya.

Pendidikan Islam neurosains holistik bertujuan memberi kebebasan anak didik untuk mengembangkan diri tidak saja secara intelektual, tapi juga menfasilitasi perkembangan jiwa dan raga secara keseluruhan sehingga tercipta peserta dan masyarakat yang berkarakter kuat dengan kemampuan mewujudkan manusia merdeka yaitu manusia yang hidupnya lahir atau batin tidak tergantung kepada orang lain, akan tetapi bersandar atas kekuatan sendiri.

Tentu tujuan diatas dapat membentuk pola masyarakat melalui system pendidikan itu sendiri dengan mengembangkan potensi individu dalam suasana pembelajaran yang lebih menyenangkan dan menggairahkan, demokratis dan humanis

\footnotetext{
${ }^{28}$ Ali Saifullah, Antara Filsafat dan Pendidikan, (Usaha Nasional, Surabaya, 1983). h. 33

${ }^{29}$ Mohammad Athiyah Abrosyi, At-Tarbiyah Al-Islamiyah Wa Falsafatuha, (Surabaya: PT Aneka Buku: 2010). h. 72
} 
melalui pengalaman dalam berinteraksi dengan lingkungannya. Melalui pendidikan neurosains holistic ini menjadi sebuah sarana pembentukan karakter moderat dan humanis masyarakat dengan instrumentasi peserta didik yang diharapkan dapat menjadi dirinya sendiri (learning to be) dan lebih khusus masyarakat dalam jangka panjang. Dalam arti dapat memperoleh kebebasan psikologis, mengambil keputusan yang baik, belajar melalui cara yang sesuai dengan dirinya, memperoleh kecakapan sosial, serta dapat mengembangkan karakter dan emosionalnya dalam kehidupan masyarakat yang ikut mempengaruhinya.

Jika merujuk pada pemikiran Abraham Maslow, maka pendidikan harus dapat mengantarkan peserta didik untuk memperoleh aktualisasi diri (self actualization) dalam suatu masyarakat sebagai basis mereka mengembangkan ilmu pengetahuan dan ikut membentuk karakter sosial masyarakat umum sehingga tercipta masyarakat yang di inginkan yakni "masyarakat Islam sebenar-benarnya". Tentu hal tersebut akan tercapai apabila yang ditandai dengan adanya kesadaran, kejujuran, kebebasan atau kemandirian dan kepercayaan.

Pendidikan neurosain holistik memperhatikan kebutuhan dan potensi yang dimiliki peserta didik, baik dalam aspek intelektual, emosional, fisik, artistik, kreatif, dan spritual. Proses pembelajaran menjadi tanggungjawab personal kolektif. Karena itu, pendidikan Islam yang berbasis neurosains holistik memerlukan strategi pembelajaran lebih diarahkan pada bagaimana mengajar orang belajar. Beberapa hal yang harus dipertimbangkan dalam mengembangkan strategi pembelajaran neurosaintis holistik, diantaranya; pendekatan pembelajaran transformatif, prosedur pembelajaran yang fleksibel, pemecahan masalah melalui lintas disiplin ilmu, pembelajaran yang bermakna, dan pembelajaran melibatkan komunitas di mana individu berada. 
Dalam pendidikan neurosaintis holistik, peran dan otoritas guru untuk memimpin dan mengontrol kegiatan pembelajaran hanya sedikit dan guru lebih banyak berperan sebagai sahabat, mentor, dan fasilitator. Forbes (1996) mengibaratkan peran guru seperti seorang teman dalam perjalanan yang telah berpengalaman dan menyenangkan. Sekolah hendaknya menjadi tempat peserta didik dan guru bekerja guna mencapai tujuan yang saling menguntungkan. Komunikasi yang terbuka dan jujur sangat penting, perbedaan individu dihargai dan kerjasama lebih utama dari pada kompetisi. Gagasan pendidikan holistik telah mendorong terbentuknya model-model pendidikan alternatif, yang mungkin dalam penyelenggaraannya sangat jauh berbeda dengan pendidikan pada umumnya, salah satunya adalah home schooling, yang saat ini sedang berkembang, termasuk di Indonesia.

Membentuk manusia secara utuh (holistik) yang berkarakter, yaitu mengembangkan aspek fisik, emosi, sosial, kreativitas, spiritual dan intelektual siswa secara optimal. Selain itu untuk membentuk manusia yang life long learners (pembelajar sejati), yakni pertama, menerapkan metode belajar yang melibatkan partisipasi aktif murid, yaitu metode yang dapat meningkatkan motivasi murid karena seluruh dimensi manusia terlibat secara aktif dengan diberikan materi pelajaran yang konkrit, bermakna, serta relevan dalam konteks kehidupannya (student active learning, contextual learning, inquiry used learning, integrated learning). Kedua, menciptakan lingkungan belajar yang kondusif (conducive learning community) sehingga anak dapat belajar dengan efektif di dalam suasana yang memberikan rasa aman, penghargaan, tanpa ancaman, dan memberikan semangat. Ketiga, memberikan pendidikan karakter secara eksplisit, sistematis, dan berkesinambungan dengan melibatkan aspek knowing the good, loving the good, and acting the good. Keempat, metode pengajaran yang memperhatikan 
keunikan masing-masing anak, yaitu menerapkan kurikulum yang melibatkan juga 9 aspek kecerdasan manusia.

Dari konsep Pendidikan Islam neurosains holistik diatas, diharapkan akan tercipta tatanan masyarakat Islam yang sebenarbenarnya. Konsepsi masyarakat Islam, adalah masyarakat yang beranggotakan orang-orang yang beriman dimana mereka telah sadar beribadah, terikat oleh pertalian batin dalam segala tindak tanduknya dan sadar kewajibannya terhadap diri sendiri maupun terhadap masyarakat serta berpendidikan..$^{30}$ Mereka memandang alam sebagai anugerah Allah untuk kesejahteraan manusia. ${ }^{31}$ Istilah Alquran yang menunjuk pada arti masyarakat Islam ideal. Sekalipun dalam Alquran tidak memberikan petunjuk secara lansung tentang suatu bentuk masyarakat yang di cita-citakan di masa mendatang. ${ }^{32}$ Namun Alquran tetap memberikan petunjuk mengenai ciri-ciri dan kualitas suatu masyarakat yang lebih baik, walaupun semua itu memerlukan upaya penafsiran dan pengembangan pemikiran.

Di samping itu Alquran juga memerintahkan kepada umat manusia untuk memikirkan pembentukan masyarakat dengan kualitas tertentu. Dengan demikian menjadi sangat mungkin bagi umat Islam untuk membuat suatu gambaran masyarakat ideal berdasarkan pejunjuk Alquran. Ada beberapa istilah yang digunakan untuk menunjuk pada arti masyarakat ideal yaitu pertama, Ummatan Wāhidah, ungkapan ini terdiri dua kata ummah dan wāhidah. Kata ummah secara umum berarti kelompok manusia atau masyarakat. Sedangkan kata wāhidah

\footnotetext{
${ }^{30}$ Abul A'la Maududi, Pokok-Pokok Pandangan Hidup Muslim, (Jakarta: Bulan Bintang, 1967), h. 47

${ }^{31}$ Shihab, M. Quraish, Tafsir Al-Misbah: Pesan, Kesan dan keserasian Alquran, vol. I, (Jakarta: Lentera Hati, 2002), h. 425

${ }^{32}$ Mahdi Fadulullah, Titik Temu Agama Dan Politik, (Solo: Ramadhani, 1991), h. 102
} 
adalah bentuk muannas dari kata wāhid secara bahasa berarti satu. $^{33}$

Kedua, ummatan wasațan, kata wasațan bermakna dasar pertengahan atau moderat yang memang menunjuk pada pegertian adil..$^{34}$ Ummatan wasațan adalah masyarakat yang berada di pertengahan dalam arti moderat. Posisi pertengahan menjadikan anggota masyarakat tidak memihak ke kiri dan ke kanan yang dapat mengantar manusia berlaku adil. Allah menjadikan umat Islam pada posisi pertengahan agar menjadi saksi atas perbuatan manusia yakni umat yang lain. ${ }^{35}$ Dengan demikian ummatan wasațan adalah umat moderat yang posisinya berada ditengah agar di lihat oleh semua pihak dari segenap penjuru. Posisi tengah menjadikan mereka mampu memadukkan aspek rohani dan jasmani, material dean spiritual dalam segala aktifitas.

Ketiga, ummatan muqtașidah, istilah ini terdapat dalam Q.S. al-Mā‘idah (5): 66:

"dan sekiranya mereka sungguh-sungguh menjalankan (hukum) Taurat dan Injil dan (Alquran) yang diturunkan kepada mereka dari Tuhannya, niscaya mereka akan mendapat makanan dari atas dan dari bawah kaki mereka. diantara mereka ada golongan yang pertengahan dan alangkah buruknya apa yang dikerjakan oleh kebanyakan mereka."

Makna kelompok pertengahan (ummatan muqtașidah) dalam ayat ini adalah sekelompok golongan yang berlaku pertengahan dalam melakukan ajarannya, tidak berlebihan dan tidak melalaikan. ${ }^{36}$ Pada awalnya ayat diatas menunjuk kepada sekelompok dari kaum Yahudi dan Nasrani. Masyarakat yang

\footnotetext{
${ }^{33}$ Lihat Mohammad Quthb, Islam di Tengah Pertarungan Tradisi, (Mizan: Bandung, 1993), h. 186.

${ }^{34}$ Zainal Abidin Ahmad, Konsepsi Politik dan Ideologi Islam, (Jakarta: Bulan Bintang, 1977), h. 163

${ }^{35}$ Lihat: Quraish Shihab, Wawasan Alquran: Tafsir Tematik atas Pelbagai Persoalan Umat, (Bandung: Mizan Pustaka, 1996), h. 328

${ }^{36}$ Ahmad Mustafa al-Maraghi, Tafsir al-Maraghi, Jilid V, (Semarang: PT. Karya Toha Putra, 1993), h. 288
} 
diideal oleh Alquran boleh jadi terdapat juga pada kelompok umat sebelum Alquran diturunkan yaitu sebuah masyarakat yang dalam sifatnya berada pada posisi pertengahan diantara dua kutub. Sifat pertengahan di isyaratkan dengan istilah qawāman yang berarti adil dan moderat. Ditegaskan bahwa sebagai anggota masyarakat seseorang muslim harus dapat bersifat benar terhadap harta yang di anugerahkan Allah. Tidak bersikap boros dan tidak bersikap menahan harta, sehingga mengorbankan kepentingan pribadi, keluarga atau anggota masyarakat yang membutuhkannya. Seorang muslim sebagai anggota masyarakat tidak boleh bersikap bakhil dan kikir sebaliknya seseorang juga tidak boleh bersikap boros terhadap hartanya.

Keempat, khairu ummah, Istilah khairu ummah berarti satu umat terbaik, disebutkan dalam Q.S. Ali 'Imrān (03): 110:

"kamu adalah umat yang terbaik yang dilahirkan untuk manusia, menyuruh kepada yang ma'ruf, dan mencegah dari yang munkar, dan beriman kepada Allah. sekiranya ahli Kitab beriman, tentulah itu lebih baik bagi mereka, di antara mereka ada yang beriman, dan kebanyakan mereka adalah orang-orang yang fasik."

Dengan mencermati ayat di atas, maka dapat ditarik definisi khairu ummah dengan melihat kriteria yang disebutkan dalam ayat tersebut adalah pertama menyuruh kepada ma'ruf. Kedua mencegah dari yang munkar dan ketiga beriman kepada Allah Swt.. Jika memperhatikan ayat ini akan diketahuai bahwa Alquran sebenarnya hanya memberikan ciri-ciri yang di gambarkan sebagai tugas dari fungsi-fungsi organik masyarakat. ${ }^{37}$

Dari gambaran diatas, dapat diperoleh penjelasan apa yang dimaksud khairu ummah yaitu pertama al-khair yang secara harfiah diterjemahkan dengan kebajikan. Kedua yang sangat populer dirumuskan sebagai amar ma'ruf nahi munkar. Amar ma'ruf tidak bisa dipisahkan dengan nahi munkar karena dalam

${ }^{37}$ Jamaluddin Kafie, Islam agama dan Negara, (Surabaya: Bina Ilmu, 1983), h. 48 
perbuatan amar ma'ruf terdapat pengertian mencegah yang munkar.

Demikian pula sebaliknya dalam pengertian nahi munkar tercakup pengertian amar ma'ruf sebab mencegah kejahatan adalah termasuk dalam perbuatan baik. Penafsiran terhadap istilah amar ma'ruf nahi munkar mengacu pada pendidikan masyarakat Islam, karena dalam kaitannya dengan pengertian khairu ummah dan ummat wasath yang di deskripsikan sebagai umat yang menegakkan keadilan. ${ }^{38}$ Alquran telah memberi petunjuk tentang khairu ummah yang dimaksud yaitu ${ }^{39}$ kumpulan orang yang memiliki kesamaan budaya. Jadi khairu ummah ialah bentuk ideal masyarakat Islam yang identitasnya adalah keimanan, komitmen dan kontribusi positif kepada masyarakat secara universal dan loyalitas pada kebenaran. Salah satunya melalui pendidikan Islam untuk menegakkan amar ma'ruf nahi munkar sebagaiman ditegaskan dalam Q.S. Ali 'Imrān (3): 104 dan 110 sehingga terciptanya masyarakat Islam yang sebenarbenarnya.

\section{PENUTUP}

Tujuan pendidikan Islam mengakomodir aspek kognitif, afektif, dan psikomotorik peserta didik yang mencakup pengetahuan, nilai, sikap dan keterampilan. Hal ini memiliki prinsip neurosains yang bersifat holistik meliputi prinsip amar ma'ruf nahi munkar, prinsip integrasi ilmu pengetahuan, prinsip keberpihakan pada kaum dhuafa, prinsip semangat pengabdian, prinsip tajdid, prinsip demokrasi dan kemasyarakatan. Dengan demikian menjadi sangat mungkin bagi umat Islam untuk membuat suatu gambaran masyarakat ideal berdasarkan pejunjuk Alquran. Pendidikan merupakan basis menciptakan masyarakat

\footnotetext{
${ }^{38}$ Ibnu Katsir, Tafsir Ibnu Katsir, Jilid I, (Bandung: Sinar Baru Algensindo, 2002), h. 359

${ }^{39}$ Al-Maraghi, Tafsir Al-Maraghi, Jilid II, (Semarang: PT. Karya Toha Putra, 1993), h. 215
} 
yang di harapkan Allah swt., seperti ummatan wāhidah, ummatan wasațan, ummatan muqtașidah dan khair ummah.

\section{DAFTAR PUSTAKA}

Abrosyi, Mohammad Athiyah, At-Tarbīyah Al-Islāmiyah Wa Falsafatuha, Surabaya: PT Aneka Buku: 2010.

Ackoff, Russell I, dan Daniel Greenberg, Turning Learning Right Side Up, Putting Education Back on The Right Track. Upper Sadle River, NJ: Pearson Ed. Inc. Canton, 2008.

Ahmad, Zainal Abidin, Konsepsi Politik dan Ideologi Islam, Jakarta: Bulan Bintang, 1977.

Ahmadi, Abu, Sosiologi, Surabaya; PT. Bina Ilmu, 1985.

Al-Maraghi, Tafsir Al-Maraghi, Jilid II dan V, Semarang: PT. Karya Toha Putra, 1993.

Alquran dan Terjemahan, Depag RI, Surabaya: Mahkota, 1989.

Anshari, Endang Saifuddin, Ilmu, Filsafat dan Agama, Jakarta: PT. Bina Ilmu, 1983.

Dryden, Gordon dan Jeannette Vos, Revolusi Cara Belajar, Bandung: Kaifa. 2000.

Fadulullah, Mahdi, Titik Temu Agama Dan Politik, Solo: Ramadhani, 1991.

Hasanuddin, Brainware Management, Jakarta: PT. Elex Media Komputindo, 2001

Ibnu Katsir, Tafsir Ibnu Katsir, Jilid I, Bandung: Sinar Baru Algensindo, 2002.

Izutsu, Toshihiko, Relasi Tuhan dan Manusia Pendekatan Semantik Terhadap Al Quran, Yogyakarta: Penerbit Tiara Wacana, 1997.

Izzududdin Taufik, Muhammad, Dalil Anfus Al-Quran dan Embriologi, Solo: Tiga Serangkai, 2006 
Kafie, Jamaluddin, Islam agama dan Negara, Surabaya: Bina Ilmu, 1983.

Kusrin, Hasanuddin Arinta, Akal: Menurut Tinjauan Al qur'an dan Neurosains, Jakarta: Universitas Indonesia, 2009.

Maududi, Abul A'la, Pokok-Pokok Pandangan Hidup Muslim, Jakarta: Bulan Bintang, 1967.

Muhadjir, Noeng, Metodologi Penelitian, Edisi VI, Yogyakarta: Rake Sarasin, 2011.

Nasution, Harun, Akal dan Wahyu Dalam Islam, Jakarta: UI Press, 1986).

Nasution, Muhammad Yasir, Manusia Menurut Al-Ghazali, Jakarta: Penerbit Rajawal Press, 1988.

Nggermanto, Agus, Quantum Qoutient (Kecerdasan Quantum): Cara Praktis Melejitkan IQ, EQ, dan SQ Yang Harmonis, Bandung: Nuansa, 2005.

Pasiak, Taufik, Manajemen Kecerdasan, Bandung : Mizan, 2006

Pasiak, Taufik, Revolusi IQ/EQ/SQ Antara Neurosains dan Al Quran, Bandung: Penerbit PT.Mizan Pustaka, 2004.

Quthb, Mohammad, Islam di Tengah Pertarungan Tradisi, Mizan: Bandung, 1993.

Saifullah, Ali, Antara Filsafat dan Pendidikan, Usaha Nasional, Surabaya, 1983.

Shihab, M. Quraish, Wawasan Alquran: Tafsir Tematik atas Pelbagai Persoalan Umat, Bandung: Mizan Pustaka, 1996

Shihab, M. Quraish, Tafsir Al-Misbah: Pesan, Kesan dan keserasian Alquran, vol. I, Jakarta: Lentera Hati, 2002.

Suyadi, "Integrasi Pendidikan Islam dan Neurosains dan Implikasinya Bagi Pendidikan Dasar (PGMI)" dalam Jurnal Al-Bidāyah, Vol 4 No. 1, (Juni 2011).

Wikipedia Bebas di Akses pada tanggal 22 April 2015. 